\title{
IMPACT OF DEMERGER'S NEWS ON SHARE PRICE
}

\author{
Raviraj Metha, Rajvi Haria, Siddharth Dholaria, Eireen Bharucha, Yash Tarphe, Harsh Shah \\ Anil Surendra Modi School of Commerce, \\ NMIMS University, Mumbai, India.
}

\begin{abstract}
A demerger is a corporate action in which a parent entity separates its business into two or more different entities. This research is analyses of change in momentum of shares price of companies and study difference in momentum of shares price before and after announcement. For this research we have taken into account 11 demerge events happened in India. For each demerges event we have taken sample $\mathbf{2 4 0}$ trading days' share price and then performed test on each event. Data of 240 trading days contains data for 120-day pre Announcement and 120 days after announcement including announcement day. The test was done to study if there is change in pattern of returns after announcement of demerger or it remains same. We found that there was difference in the pattern of returns after announcement when compared with before announcement.
\end{abstract}

\section{INTRODUCTION}

A demerger is an old phenomenon first introduced in America somewhere in 1920s. A demerger is a corporate event in which a company separates one or more divisions into different entities in order to increase its effectiveness and focus towards a particular business and let demerged venture to thrive with different management.

Demerge is a very effective strategy for companies who want to increase their focus towards a particular business and let demerged entity run under other professional management.

Demerge are generally are of two types:

- Spin-off: Spinoff is a situation in which company transfers all the assets and liabilities to different company who thereafter continues with that entity conducting business. For example: Company XYZ an electronics has three divisions in their company i.e. division $\mathrm{X}$ manufactures Power bank, division $\mathrm{Y}$ Manufactures Audio Devices and division $\mathrm{Z}$ Manufactures Smartphones. XYZ decided to sell their division $Y$ that is the Audio Device division. $\mathrm{XYZ}$ now need to transfer all the assets and liabilities of division $\mathrm{Y}$ to other company and continue to run $\mathrm{X} \& \mathrm{Z}$ divisions.

- Split off: It is a transfer of all the assets, liabilities and business to two or more companies which is same as a spin-off but in this company also need to allot original shareholders shares of new company in proportionate manner which is different than spin-off in which division which is sold ceases to exist. For example: a company XYZ an electronics company decided to transfer share of its all 3 divisions to different companies and each investor gets proportionate shares of other three companies and XYZ will cease to exist.

A demerger is a sensible option when there are negative synergies between different departments and their coexistence is having negative impact on each other's business.

\section{Disadvantage of Demerger}

Generally, a merger happens so that companies can work in synergy and improve each other's productivity by using each other's resources, knowhow, expertise and management techniques.

Unwinding a merger is not always an easy task it requires large amount of regulatory work to conduct a successful demerger. Firms surviving a demerger are likely to be, at least for some time, weaker than they were before the merger. In extreme cases, viability of one or both firms may be at stake.

Selection of topic

A demerger is not a usual phenomenon happening in market. This study was done to recognize is there any pattern that exists in returns form shares before and after announcement of demerger as share price also reflects sentiment. This research also helps us study change in investor sentiment after announcement of demerger.

\section{LITERATURE REVIEW}

A demerger is strategy used by the companies to focus on its core business and to sell-off its 


\section{International Journal of Engineering Applied Sciences and Technology, 2019 \\ Vol. 4, Issue 6, ISSN No. 2455-2143, Pages 133-137 \\ Published Online October 2019 in IJEAST (http://www.ijeast.com)}

demerged company during demerger, the assets and liabilities of a parent company are transferred to the new company. The new company, after it has demerged, issues new shares to the existing shareholders of the parent company without receiving cash. This results in no economic significance in the face value of new shares.

The primary method for evaluation of a corporation's performance is by value creation. But, what method should we adopt to calculate value creation. According to Rappaport et al. (1986), an increase in market capitalization can be used to calculate value creation.

There is a general assumption among researchers that demergers can create value for shareholders. This is based on many pieces of research done in US on announcement of demergers which had created unnatural returns of stock price to shareholders.

As per Gailen L. HITE et al.(1983), "If there are no synergies between the parent and the subsidiary, the sum of the post-divestitures' cash flows would equal the combined cash flow had the two units remained as one." This means that the net value of demerged companies should be same as the previous amalgamated parent companies. there can be increase or decrease in value if there are positive or negative synergies respectively.

A paper by Kirchmaier et al.(2003) statistically proves that there is a positive reaction of $+5.5 \%$ after the demerger announcement. He divided the time period into 4-parts: pre-announcement, announcement, post-announcement and time after actual demerger. Prior to announcement, there is underperformance of company in the market, but it recovers after the announcement. Also, the small demergers are more successful than a large demerger.

In another paper by Singh, Bhowal, \& Bawari et al. (2009) the shareholders' wealth had increased after the demergers. It has also decreased when the demerger was hyped with the aim of manipulation. So, the investors should examine the quality of management when there is demerger.

\section{RESEARCH METHODOLOGY}

The research methodology is the technique to thoroughly solve the research problem. It may be understood as a science of studying how research is done scientifically. A researcher should think about the way in which he should proceed to attain his objective in his research. This plan of study of a researcher is called a research design. A combination of Descriptive and Inferential statistics is used for this study.

In this methodology, the aims, objectives and hypotheses are defined, followed by an elaboration on which data collection methods were used.

\section{Research Objective}

The initial objectives, which had been defined for the research proposal, have been redefined and made more specific and focused. The objectives stated underneath are the ones that have been redefined and were used for the analysis of the results. To analyse the effect of announcement of demerger of a company on its share price.

\section{Research Hypothesis}

In order to follow the research methodology, the following two, alternate and null hypothesis are laid down:

$\mathrm{H}_{0}$ : There is no significant difference in the returns.

$\mathrm{H}_{1}$ : There is a significant difference in the returns.

\section{Data Collection}

Data Collection is a process of collecting information from all the relevant sources to test the hypothesis and evaluate the outcomes. Data collection methods can be divided into two categories: secondary methods of data collection and primary methods of data collection.

The method used in this research is the secondary method of data collection. It consists of data from newspapers and online portals.

The sample data collected consists of 11 companies each having 120 days closing prices pre and 120 days closing prices post the announcement of the demerger.

\section{Test Statistic}

The test statistic used for testing the hypothesis is paired t-test since our sample size $(n=11)$ is less than 30. The software used for the test is IBM SPSS. SPSS is short for Statistical Package for the Social Sciences, the software offers advanced statistical analysis, a vast library of machine-learning algorithms, text analysis, open-source extensibility, integration with big data and seamless deployment into applications. Its ease of use, flexibility and scalability make IBM SPSS accessible to users with all skill levels and outfits projects of all sizes and complexity. IBM SPSS is the world's leading statistical software designed to solve business and research problems by means of ad hoc analysis, hypothesis testing, geospatial analysis and predictive analytics. Organizations use IBM SPSS Statistics to understand data, analyse trends, forecast and plan to validate assumptions and drive accurate conclusions. 


\section{ANALYSIS AND FINDINGS}

\section{Statistical test for Significance:}

We are analysing the change in the mean of daily returns for 120 days period, for 120 days daily returns before the demerger news came into the public domain and 120 days after the news came into public domain, considering the demerger news announcement day into later 120 days.

The daily Log returns are calculated as follows:

$$
\begin{aligned}
& \text { Daily Returns } \\
& =\text { LN } \frac{\text { Current Day Closing Price }}{\text { Previous Day Closing Price }}
\end{aligned}
$$

For example, if previous day closing price is 102 and current day closing price is 104 we calculate the daily Log returns as follows:

$$
\begin{aligned}
& \text { Daily Log Returns }=\ln (104 / 102) \\
= & \ln (104)-\ln (102) \\
= & 4.6444-4.6250 \\
= & 0.0194 \text { or approx. } 1.94 \%
\end{aligned}
$$

Note: Figures are rounded to the $4^{\text {th }}$ decimal place

We have calculated the daily returns for 120 trading days as per above example. The calculated daily Log returns are our data sets to perform the test for mean daily returns before the demerger announcement comes into public domain and similarly for the daily returns for 120 trading days after the demerger announcement comes into public domain.

Here we have designated the company names as $\mathrm{C} 1, \mathrm{C} 2, \mathrm{C} 3 \ldots, \mathrm{C} 11$ instead of mentioning their actual names, although the data have been collected for actual companies with respect to their demerger announcement news.

Daily mean returns have been calculated by taking arithmetic mean of all the daily Log returns for Pre-demerger news announcement and Postdemerger news announcement. These means are signified by suffix 'PRE' and 'POST' with the respective company name.

For example, the mean of daily Log returns for Predemerger news announcement and Post-demerger news announcement of Company 1 is signified as 'C1PRE' for Pre-demerger news announcement and 'C1POST' for Post-demerger news announcement.

For the analysis, the pair of paired t-test compares the means for daily Log returns of Pre-demerger news announcement and Post-demerger news announcement scenario i.e. Pair 1 compares the significant change in the means of C1PRE and C1POST.

\section{Paired t-test:}

Paired t-test has been used to do the hypothesis testing mentioned in the Methodology.

The paired sample $t$-test, sometimes called the dependent sample $t$-test, is a statistical procedure used to determine whether the mean difference between two sets of observations is zero. In a paired sample $t$-test, each subject or entity is measured twice, resulting in pairs of observations.

In paired t-test we compare the difference $\bar{d}$ is compared with 0 for the significance.

\section{$\mathbf{t}_{\text {cal }}$ calculation:}

$$
t_{\text {cal }}=\frac{\bar{d}}{S_{d} / \sqrt{n}}
$$

To study the effect of demerger on daily returns of a stock, 11 listed companies have been taken under consideration. By considering overall, the 240 trading days for a company we can minimize the effect of seasonality, annual reports, and any factors which have annual implication on the stock price are taken into the picture. Since on an average there are 252 trading days in a year in Indian stock exchange, sample size of 240 days can account for most of the annually occurring changes in the stock price.

Note: For Company C2 and C10, 238 days and 236

\begin{tabular}{|c|c|c|c|c|}
\hline & & $t$ & df & Sig. (2-tailed) \\
\hline Pair 1 & C1PRE-C1POST & .498 & 119 & .620 \\
\hline Pair 2 & C2PRE - C2POST & -2.050 & 118 & .043 \\
\hline Pair 3 & C3PRE - C3POST & .490 & 119 & .625 \\
\hline Pair 4 & C4PRE - CAPOST & .005 & 119 & .996 \\
\hline Pair 5 & C5PRE - C5POST & -2.325 & 119 & .022 \\
\hline Pair 6 & C6PRE - C6POST & 1.585 & 119 & .116 \\
\hline Pair 7 & C7PRE - C7POST & .745 & 119 & .458 \\
\hline Pair 8 & C8PRE - C8POST & 1.197 & 119 & .234 \\
\hline Pair 9 & CIPRE - C9POST & -1.007 & 119 & .316 \\
\hline Pair 10 & C1OPRE - C1OPOST & 1.596 & 117 & .113 \\
\hline Pair 11 & C11PRE - C11POST & -1.321 & 119 & .189 \\
\hline
\end{tabular}
trading day closing price is considered

Below is the table for all 11 listed companies taken under consideration for the paired t-test.

The results have 3 columns naming $t$, df, Sig (2tailed) signifying $t_{c a l}$ value, degrees of freedom and significance respectively.

\section{Figure 1 Output from IBM SPSS}




\section{International Journal of Engineering Applied Sciences and Technology, 2019 \\ Vol. 4, Issue 6, ISSN No. 2455-2143, Pages 133-137 \\ Published Online October 2019 in IJEAST (http://www.ijeast.com)}

$\mathrm{t}_{\text {tab }}$ value (value taken from $\mathrm{t}$-table) for $95 \%$ Level of Significance and $119 \mathrm{df}$ is 1.645 and 1.645 for 118 $\& 117 \mathrm{df}$.

From the results achieved by paired t-test, we compare the $t_{\text {cal }}$ and $t_{\text {tab }}$ values for each of the pair.

When $t_{\text {cal }}>t_{\text {tab }}$; the change in means (pre and post) is significant

Only company $\mathrm{C} 2$ and $\mathrm{C} 5$ shows the significant difference in the mean daily returns of pre-demerger announcement mean daily returns and postdemerger announcement mean daily returns.

Hence we fail to reject the $\mathrm{H}_{0}$ (null hypothesis) for $\mathrm{C} 2$ and $\mathrm{C} 5$

p-value:

We are testing the mean at $95 \%$ Confidence interval.

Hence any value from column $3<0.05$, falls outside the acceptance range. i.e. the value is not significant at level of significance of $5 \%$

Only company C2 and C5 satisfies above condition and shows the same results. Daily returns of days around announcement

\begin{tabular}{|c|c|c|c|c|c|c|c|c|c|c|c|}
\hline \multicolumn{12}{|c|}{ t-values of daily returns around the demerger announcement } \\
\hline Davs & Cl & Q & Q3 & C4 & C5 & C6 & Cl & C8 & C & C10 & C11 \\
\hline .5 & -0.2255 & -0.2485 & 0.1331 & 0.2670 & -0.0843 & 0.5747 & -0.7895 & $-1,2340$ & -0.1515 & 0.2196 & 1.9364 \\
\hline .4 & -0.5034 & 0.1302 & -2.0725 & -12806 & .021142 & 0.472 & -1.0444 & -0.0537 & 0.4772 & -0.6013 & -0.7415 \\
\hline .3 & $-4,0095$ & $-4,7588$ & 0.1215 & .08085 & -0.0813 & 0.5926 & -0.4735 & 0.1107 & 0.3366 & 0.0894 & 0.5763 \\
\hline .2 & 0.1950 & $-1,17789$ & 0.8338 & 0.6487 & -0.0843 & $-1,050$ & $\cdot-1,3172$ & 1.8411 & -0.3034 & -0.8662 & -0.0690 \\
\hline .1 & -17838 & 0.4187 & 2.4702 & 22550 & $\cdot 0.0314$ & 0.5567 & -0.1712 & 2.0734 & 0.8049 & -0.2141 & 0.1140 \\
\hline 0 & 4,7529 & -1.3130 & -0.7062 & -3.21424 & -0.0489 & -2.8512 & 0.2310 & -0.7177 & 4.6126 & -0.8010 & 0.9160 \\
\hline 41 & .25532 & -1.0543 & .0 .3646 & .04094 & -0.1551 & 0.07762 & -0.6453 & 0.1982 & 1.6599 & -0.8913 & -0.5693 \\
\hline+2 & 13173 & 1.6620 & -1.6994 & 1.1360. & -0.0961 & -0.4055 & 0.9626 & 1.3403 & 1.6448 & 0.0072 & 1.1315 \\
\hline+3 & 12060 & -1.3586 & -0.5592 & 1058 & 0.1533 & 0.7426 & 0.1225 & 0.6813 & 1.6477 & -0.1118 & -0.3376 \\
\hline+4 & -0.7049 & -0.1314 & 0.0219 & . 19953 & -0.2513 & -0.1334 & -0.2829 & .0 .5711 & 13800 & 0.6655 & -1.7908 \\
\hline+5 & 1.0587 & $-1,0109$ & -0.8790 & 0.1142 & 0.08860 & 0.6840 & -0.7932 & .03886 & .13724 & .0 .4101 & 0.6998 \\
\hline
\end{tabular}

The $0^{\text {th }}$ day is the news announcement date and $\mathrm{t}-$ values of daily returns for 5 days before demerger announcement and 5 days after demerger announcement is shown in table.

For most of the companies, it has been observed that on the $0^{\text {th }}$ day or days around this day the $t$ value is significant than other usual trading days. Which implies that on the $0^{\text {th }}$ day a stock has the abnormal returns which is the impact of news on the stock.

Note: Other trading days can also show the abnormal returns because of different reasons which would be company-specific which need to be ignored to perform the study.

The method to calculate the daily Log returns is as same as mentioned above.

\section{CONCLUSION}

The main motive of any company getting into a demerger agreement is to improve its synergies as separate entities. Companies who feel that their subparts might perform well individually rather than as a single unit opt for a demerger. The decision of going for a demerger is not simple but rather a process that requires in-depth analysis. This is because a decision from the company's side can have repercussions on all the stakeholders associated. Hence this paper aims to study the reaction of one of the stakeholders i.e. the shareholders. This paper observes the reaction of the shareholders from the movement in the daily share price of the company. As soon as the shareholders or any other individual is made aware of a company going in for a demerger, it is but natural for them to interpret it in a positive, negative or neutral manner. This paper aims to see the reflection of this interpretation in the daily returns of the parent company.

From the sample of 11 companies that have emerged, it has been observed that in the longer time period i.e. 120 days' Pre-demerger news announcement and 120 days Post-demerger news announcement there is no significant change in the mean. Whereas, in the short term i.e. the time period around the news announcement there was a significant change observed in the daily returns of the company's share price.

It can be hence concluded that we Reject $\mathrm{H}_{0}$ for the shorter term close to the demerger news announcement. This is the time when the actual public reaction can be observed. As time passes, the effect of the news phases out and investors instead of relying solely on sentiment start to consider the fundamentals of the company and track its performance. Hence in the longer term we can see that the impact of the demerger news announcement doesn't have a significant impact.

\section{REFERENCE}

[1] Hite, G. L., \& Owers, J. E. (1983). Security price reactions around corporate spin-off announcements. Journal of Financial Economics, 409-436.

[2] Kirchmaier, T. (2003). The Performance Effects of European Demergers. The Centre for Economic Performance, London School of Economics and Political Science. 
[3] Rappaport, A. (1986). Creating Shareholder Value: The New Standard for Business Performance. New York: Simer and Schuster Publishing Group.

[4] Singh, R., Bhowal, A., \& Bawari, V. (2009). Impact of Demerger on Shareholders' Wealth. Macrothink Institute, (pp. 44-59).

[5] Vijh, A. (1994). The Spinoff and Merger Ex-Date Effects. The Journal of Finance, 49(2), 581-609. doi:10.2307/2329164

[6] Bendre, M., Apte, N. (10, October, 2017), study of impact of spin-offs on shareholders wealth in India. International research journal of multidisciplinary studies

[7] Yahoo Finance For Data

- https://in.finance.yahoo.com/

[8] Juneja, P. (n.d), What are Demergers: Its Pros and Cons. Retrieved from https://www.managementstudyguide.com/ what-is-demergers.htm

[9] Shamika, V. (14, March ,2019), Demerger and Five Reasons Why it is used. . Retrieved from https://blog.ipleaders.in/demergers-andtheir-use/

[10] Cusatis, Patrick, James Miles, and Randall Woolridge, 1993, Restructuring through spinoffs: The stock market evidence, Journal of Financial Economics 33, 293-311.

[11] Dennis, Debra, and John McConnell, 1986, Corporate mergers and security returns, Journal of Financial Economics 16, 143-187.

[12] Dodd, Peter, 1980, Merger proposals, management discretion and stockholder wealth, Journal of Financial Economics 8, 105-137.

[13] Eades, Kenneth, Patrick Hess, and Han Kim, 1984, On interpreting security returns during the ex-dividend period, Journal of Financial Economics 13, 3-24. 